\title{
Epidemiology of hepatitis E virus infection in animals in Africa: a systematic review and meta-analysis
}

Abdou Fatawou Modiyinji 1,2, Jean Joel Bigna ${ }^{3,4}$, Sebastien Kenmoe ${ }^{1}$, Fredy Brice N. Simo 1,3, Marie A. Amougou ${ }^{1,3}$, Marie S. Ndangang ${ }^{5}$, Moise Nola ${ }^{2}$ and Richard Njouom ${ }^{1 *}$

\begin{abstract}
Background: Hepatitis E virus (HEV) is a major cause of acute hepatitis in humans worldwide and have high burden in the resource-limited countries. Better knowledge of the epidemiology of hepatitis in animals in Africa can help to understand the epidemiology among humans. The objective of this study was to summarize the prevalence of HEV infection and distribution of HEV genotypes among animals in Africa.

Methods: In this systematic review and meta-analysis, we comprehensively searched PubMed, EMBASE, African Journals Online, and Africa Index Medicus from January 1st, 2000 to March 22th, 2020 without any language restriction. We considered cross-sectional studies of HEV infection in animals in Africa. Study selection, data extraction, and methodological quality of included studies were done independently by two investigators. Prevalence data were pooled using the random-effects meta-analysis. This review was registered in PROSPERO, CRD42018087684.
\end{abstract}

Results: Twenty-five studies (13 species and 6983 animals) were included. The prevalence (antibodies or ribonucleic acid [RNA]) of HEV infection in animals varied widely depending on biological markers of HEV infection measured: 23.4\% (95\% confidence interval; 12.0-37.2) for anti-HEV immunoglobulins G, 13.1\% (3.1-28.3) for anti-HEV immunoglobulins $\mathrm{M}$, and 1.8\% (0.2-4.3) for RNA; with substantial heterogeneity. In subgroup analysis, the immunoglobulins $\mathrm{G}$ seroprevalence was higher among pigs 37.8\% (13.9-65.4). The following HEV genotypes were reported in animals: Rat-HEV genotype 1 (rats and horses), HEV-3 (pigs), HEV-7 (dromedaries), and Bat hepeviruses (bats).

Conclusions: We found a high prevalence of HEV infection in animals in Africa and HEV genotypes close to that of humans. Some animals in Africa could be the reservoir of HEV, highlighting the need of molecular epidemiological studies for investigating zoonotic transmission.

Keywords: Hepatitis E, Epidemiology, Africa, Animals, Veterinary

\footnotetext{
* Correspondence: njouom@pasteur-yaounde.org

${ }^{1}$ Department of Virology, Centre Pasteur of Cameroon, Yaoundé, Cameroon

Full list of author information is available at the end of the article
}

(c) The Author(s). 2021 Open Access This article is licensed under a Creative Commons Attribution 4.0 International License, which permits use, sharing, adaptation, distribution and reproduction in any medium or format, as long as you give appropriate credit to the original author(s) and the source, provide a link to the Creative Commons licence, and indicate if changes were made. The images or other third party material in this article are included in the article's Creative Commons licence, unless indicated otherwise in a credit line to the material. If material is not included in the article's Creative Commons licence and your intended use is not permitted by statutory regulation or exceeds the permitted use, you will need to obtain permission directly from the copyright holder. To view a copy of this licence, visit http://creativecommons.org/licenses/by/4.0/. The Creative Commons Public Domain Dedication waiver (http://creativecommons.org/publicdomain/zero/1.0/) applies to the data made available in this article, unless otherwise stated in a credit line to the data. 


\section{Background}

Worldwide, hepatitis E virus (HEV) is a major cause of acute hepatitis in humans. HEV belongs to the family of Hepeviridae and consists of a non-segmented, nonenveloped and single-stranded ribonucleic acid (RNA) $[1,2]$. This family is divided into the two genera: Orthohepevirus and Piscihepevirus [1,3]. Four species designated as Orthohepevirus $A$ to $D$ are found in the genus Orthohepevirus [3]. Orthohepevirus A contains eight genotypes (HEV-1 to HEV-8) [1, 4]. HEV-1 and HEV-2 are exclusively detected in humans. These two genotypes are responsible for large hepatitis $\mathrm{E}$ outbreaks described in developing regions like Africa and Asia. HEV-3 and HEV-4 are present in humans and other animals, and are the main cause of sporadic infection among humans in developed countries. These two genotypes are considered zoonotic, and pigs and other animal species are reservoir of viruses infecting humans [5]. HEV-5 and HEV6 have been identified in japanese wild boars [6]. HEV-7 has been described recently in an immunocompromised transplant patient and in dromedary camels $[7,8]$. HEV8 was detected recently in Bactrian camels in China [4]. Orthohepevirus $B$ contains four subtypes (I-IV) of avian viruses identified mainly in domestic chicken. Two genotypes detected in rats (HEV-C1) and carnivores (HEVC2) belong to Orthohepevirus C. Different bat species represent the animal reservoirs for Orthohepevirus $D$ strains $[1,5,9,10]$. Piscihepevirus $A$ identified in cutthroat trout and related species is only one species described in the genus Piscihepevirus [1].

In 2010, one-third of the world's population has been infected with HEV [11]. A case-fatality rate of $1-4 \%$ in the general population might reach $30 \%$ in pregnant women infected with HEV-1. In addition, chronic disease courses could be observed in immunocompromised transplant patients infected with HEV-3 $[12,13]$. HEV causes large outbreaks and sporadic cases of acute hepatitis [14]. There is heterogeneity in the distribution of HEV as cause of acute hepatitis; with HEV responsible for more than $50 \%$ of the acute hepatitis infections in some countries like India, 15-20\% in Eastern-Oriental countries, and $25 \%$ in Africa [15].

The systematic review published by Kim and colleagues in 2014 provided an overview of the epidemiology of HEV infection in humans in Africa. Since 1979, 17 HEV outbreaks have been reported, around once every year in Africa; causing a reported 35,300 cases with 650 deaths. Three HEV genotypes (HEV-1, 2 and 3) have been detected in humans in Africa and it appears that HEV-1 is most prevalent than HEV-2 and HEV-3 [14]. Animals might therefore play a role in the transmission of HEV in Africa as in developed countries. However, evidence of zoonotic transmission in Africa is not well established. Therefore, better knowledge of the epidemiology of HEV in animals in Africa can help to understand the epidemiology among humans and consequently help to design better strategy to curb the burden of HEV infection in Africa through interventions in animals and on interaction between humans and animals.

The objective of this study was to describe the epidemiology of HEV infection in animals in Africa based on a systematic review and meta-analysis. We specifically aimed to summarize data on the seroprevalence and viral prevalence of HEV infection in animals in Africa. We also aimed to identify different HEV genotypes found in animals in Africa, to investigate whether animal in Africa might represent a HEV reservoir.

\section{Methods}

Design

This systematic review with meta-analysis was registered in PROSPERO, CRD42018087684 and the protocol was published in a peer-review journal [16]. This review was reported according to PRISMA guidelines [17]. This systematic review and meta-analysis was conducted as recommended in the Joanna Briggs Institute reviewer's manual for prevalence and incidence review [18].

\section{Criteria for considering studies for this review Types of participants}

We considered animals living in Africa regardless of age and sex. We excluded studies performed in laboratory animals, studies conducted in animals imported in the Africa continent, studies in which sample were not directly collected in animals (like feces in the breeding areas), and studies reporting HEV cases imported from outside Africa.

\section{Types of outcomes}

- HEV prevalence based on the biological markers including serological markers like immunoglobulins (Ig) $\mathrm{G}$ and Ig $\mathrm{M}$ or molecular markers like HEV RNA measured by reverse transcriptase polymerase chain reaction.

- HEV genotypes identified by molecular techniques.

\section{Types of studies}

We considered only cross-sectional studies.

\section{Search strategy and identification of studies}

We searched Medline through PubMed, Exerpta Medica Database, African Journals Online, and Africa Index Medicus from January 1st, 2000 to March 22th, 2020 without any language restriction. We manually searched the reference list of all relevant articles and reviews to identify additional articles. The full search strategy in PubMed is available in the published protocol [16]. This 
search strategy was built according to PRESS guidelines [19]. In brief, text words and medical subject heading terms; and their variants were used. These terms included "Hepatitis E", "Africa", and individual names of African countries and regions; with a filter for animals.

Two review authors independently read titles and abstracts of the identified references and eliminated obviously irrelevant studies. These two review authors independently retrieved full-text articles for the references that remained, and examined potentially relevant studies, using the predetermined inclusion criteria. Existing disagreements were solved by a third review author.

\section{Data extraction and management}

Two review authors independently extracted data from the included studies. Data were double checked by a third author. Data extracted included name of first author, year of publication, period of recruitment, types of genotypes, site of recruitment, sampling method, species, number of animals examined, number of animals infected with hepatitis E virus, ascertainment of HEV infection, age distribution, and proportion of male animals. We extracted data by animal species even coming from a unique study considering therefore each species in each study as the unit of analysis.

\section{Assessment of the methodological quality}

An adapted version of the risk of bias tool for prevalence studies developed by Hoy and colleagues has been used to evaluate the methodological quality of included studies [20]. The defined items were scored with 0 for 'No' and 1 for 'Yes'. The total score of each included study was calculated by the sum of its items. Methodological quality was considered as low, moderate, and high for scores of $0-4,5-7$ and $8-10$, respectively. Two review authors assessed the methodological quality and disagreements were solved through a consensus or by an arbitration of a third review author.

\section{Data synthesis and analysis}

Data analysis was conducted using the "meta" packages of the $R$ statistical software (version 3.6.2, The $R$ Foundation for statistical computing, Vienna, Austria). The prevalence of $\mathrm{HEV}$ infection was recalculated on the basis of numerators and denominators provided by individual studies. To minimize the effect of studies with extremely small or extremely large prevalence estimates on the overall estimate, the variance in study-specific prevalence was stabilized with Freeman-Tukey arc-sine transformation before pooling the data with the random effects meta-analysis model [21]. Heterogeneity was assessed by the chi-square test on Cochran's Q test [22], which was quantified by $\mathrm{I}^{2}$ values, assuming $\mathrm{I}^{2}$ values of 25,50 and $75 \%$ respectively representative low, medium and high heterogeneity [23]. When substantial heterogeneity was detected $\left(\mathrm{I}^{2}>50 \%\right)$, we performed subgroup analysis by animal species to investigate possible sources of heterogeneity (for studies with 10 more animals by species). The Egger test was performed to assess the presence of publication bias and selective reporting [24]. A $p$ value $<0.10$ was considered indicative of a statistically significant publication bias. We synthesized data on genotypes in the narrative format.

\section{Results}

\section{The review process}

Initially, a total of 514 records were identified. One hundred and forty duplicates were removed. After screening titles and abstracts, 319 records were found irrelevant and then excluded. Agreement between review authors on abstract selection was high (Kappa $=0.85, p<0.001$ ). Full-texts of the remaining 55 records were scrutinized for eligibility, among which 30 were excluded. Finally, 25 studies were retained (Fig. 1) [8, 25-48].

\section{Characteristics of included studies}

Studies were published between 2006 and 2020. Animals were included in studies between 1983 and 2018. Nine, five, and three studies were from rural, urban and both settings. Eight studies did not specify the setting. Sampling was consecutive and random in 13 and 12 studies respectively. Data were collected prospectively and retrospectively in 20 and five studies respectively. Data were from 19 countries. Five (20\%) studies had low, 16 (64\%) moderate, and four (16\%) high risk of bias (Supplementary Table 1).

\section{Prevalence of HEV infection in animals in Africa}

In total, data were from 6983 animals including 13 species (Bats $(n=1417)$, Buffaloes $(n=57)$, Chicken $(n=1)$, Cows and Beefs $(n=74)$, Donkeys $(n=47)$, Dromedaries $(n=1483)$, Ducks $(n=1)$, Goats and Sheep $(n=404)$, Horses $(n=200)$, Monkeys $(n=173)$, Pigs $(n=2721)$, Rabbits $(n=173)$, and Rats $(n=43))$.

The prevalence of HEV infection in animals varied widely depending on biological markers: 23.4\% (95\% confidence interval; 12.0-37.2) for anti-HEV IgG, 13.1\% (3.1-28.3) for anti-HEV IgM, and $1.8 \%(0.2-4.3)$ for HEV RNA with substantial heterogeneity (Table 1). The 95\% prediction interval was wide for anti-HEV IgG and anti-HEV IgM. There was no publication bias (Table 1) as indicated by funnel plots for anti-HEV IgG and RNA (Supplementary Figs. 1 and 2).

When considering subgroup analysis by specie, the viral HEV prevalence varied from $0 \%$ in rabbits to $16.7 \%$ in goats and sheep with significant difference between species considering RNA, $p<0.0001$ (Fig. 2). The IgG seroprevalence varied from $0.0 \%$ in cows and beefs to 


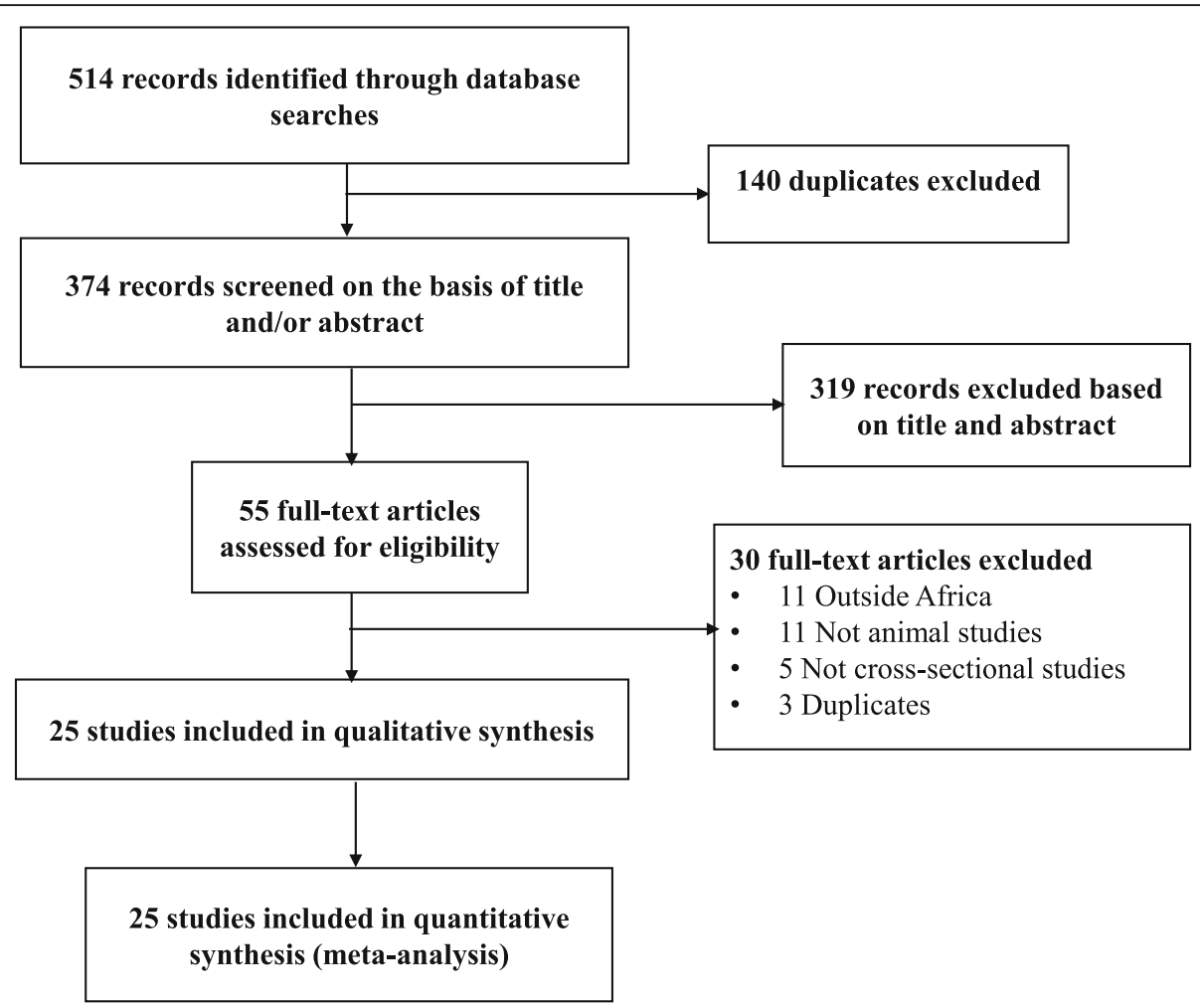

Fig. 1 The review process

$35.1 \%$ in pigs with significant difference between species, $p<0.0001$ (Fig. 3). IgM seroprevalence varied from $0 \%$ in cows and beefs to $25.8 \%$ in goats and sheep, $p<0.0001$ (Fig. 4).

\section{HEV genotypes in animals in Africa}

The following four HEV genotypes were reported by 10 studies: rat-HEV genotype 1, Bat hepevirus, HEV-3, and HEV-7 (Table 2). Seven studies demonstrated the presence of HEV-3 in pigs in Cameroon, Democratic Republic of Congo, Nigeria, São Tomé and Príncipe, Madagascar and Burkina Faso. Rat-HEV genotype 1 was found in rats and horses in Egypt. HEV-7 was found in dromedaries in Somalia and Kenya. Additionally, bat hepevirus was found in bats in Ghana and Gabon (Table 2).

\section{Discussion}

This systematic review with meta-analysis reveals that the prevalence of HEV infection in animals varied widely depending on biological markers: $23.4 \%$ with IgG, $13.1 \%$ with IgM, and $1.8 \%$ with RNA. We also found a substantial heterogeneity in the overall IgG and IgM seroprevalence and viral prevalence that was explained by difference in the HEV distribution among different animal species. Pigs presented the highest IgG seroprevalence of $35.1 \%$ followed by dromedaries, cows and beefs, and goats and sheep with IgG seroprevalence between 10 and 15\%. Donkeys, pigs, rats, and goats and sheep presented a viral prevalence of more than 3\%. Pigs, goats, and sheep presented an IgM seroprevalence higher than $10 \%$ compared to others. Four genotypes were identified in animals in Africa: rat-HEV genotype 1, HEV-3, HEV-7 and bat hepevirus.

Table 1 Summary statistics of meta-analysis prevalence of hepatitis E virus infection in animals in Africa

\begin{tabular}{|c|c|c|c|c|c|c|c|}
\hline \multirow[t]{2}{*}{ Biological markers } & \multirow{2}{*}{$\begin{array}{l}\text { Prevalence, \% } \\
(95 \% \\
\text { confidence } \\
\text { interval) }\end{array}$} & \multirow{2}{*}{$\begin{array}{l}\text { Studies, } \\
\mathrm{n}\end{array}$} & \multirow{2}{*}{$\begin{array}{l}\text { Animals, } \\
\mathrm{n}\end{array}$} & \multicolumn{3}{|l|}{ Heterogeneity } & \multirow{2}{*}{$\begin{array}{l}P \\
\text { Egger test }\end{array}$} \\
\hline & & & & 95\% Prediction interval & $\mathrm{I}^{2}, \%$ & $P$ value & \\
\hline Ribonucleic acid & $1.8(0.2-4.3)$ & 14 & 4621 & $0.0-17.0$ & 94.6 & $<0.0001$ & 0.174 \\
\hline Immunoglobulins M & $13.1(3.1-28.3$ & 5 & 1174 & $0.0-81.1$ & 97.6 & $<0.0001$ & 0.755 \\
\hline Immunoglobulins G & $23.4(12.0-37.2)$ & 14 & 3016 & $0.0-83.3$ & 98.6 & $<0.0001$ & 0.450 \\
\hline
\end{tabular}


Author, Year

Bats

Drexler, 2012

Subgroup prevalence

Heterogeneity: not applicable

Donkeys

Guerrero-Latorre, 2011

Guthmann, 2006

Subgroup prevalence

Heterogeneity: $I^{2}=69.6 \%$

Dromedaries

Li, 2017

Rasche, 2016

Subgroup prevalence

Heterogeneity: $I^{2}=0 \%$

Goats and Sheeps

Ghoneim, 2016

Subgroup prevalence

Heterogeneity: not applicable

\section{Horses}

Saad, 2007

Subgroup prevalence

Heterogeneity: not applicable

\section{Pigs}

de Paula, 2013

Kaba, 2010

Mesquita, 2019

Owolodun, 2014

Temmam, 2013

Traoré, 2015

Subgroup prevalence

Heterogeneity: $I^{2}=96.1 \%$

\section{Rabbits}

Isaeva, 2015

Subgroup prevalence

Heterogeneity: not applicable

\section{Rats}

Ghoneim, 2016

Subgroup prevalence

Heterogeneity: not applicable

Test for subgroup differences: $p<0.0001$
1417

1417

28

19

47

246

1104

1350

30

30

200

200

345

40

80

376

250

257

1348

173

173

43

43

Sample Prevalence (\%) $[95 \%$ C.I. $]$

Prevalence (\%)

$0.1 \quad[0.0 ; 0.5]$

$0.1[0.0 ; 0.4]$

$0.0 \quad[0.0 ; 12.3]$

$10.5[1.3 ; 33.1]$

$3.0[0.0 ; 20.1]$

$0.0 \quad[0.0 ; 1.5] \vdash$

$0.3 \quad[0.1 ; 0.8]+$

$0.2[0.0 ; 0.5] \nabla$

$16.7 \quad[5.6 ; 34.7]$

$16.7[5.1 ; 32.4]$

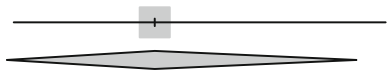

$2.0 \quad[0.5 ; 5.0]+$

$2.0[0.4 ; 4.5]$

$0.9 \quad[0.2 ; 2.5]+$

$2.5 \quad[0.1 ; 13.2]$

$6.2[2.1 ; 14.0]$

$18.4[14.6 ; 22.6]$

$1.2[0.2 ; 3.5]+$

$0.4 \quad[0.0 ; 2.1]+$

$3.5[0.0 ; 10.7]$

$0.0 \quad[0.0 ; 2.1] \vdash$

$0.0[0.0 ; 1.0] \triangleright$

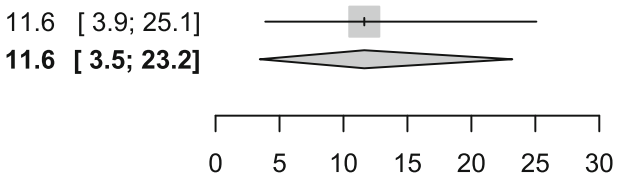

Fig. 2 Meta-analysis of viral prevalence of HEV infection in animals in Africa

The seroprevalence (IgM 16.9\% and IgG 35.1\%) and viral prevalence $(3.5 \%)$, we found among pigs overlap prevalence estimates from other countries outside Africa [49]. Like in Africa, there is a wide variation in IgG seroprevalence in pigs living in other regions including North America (35-59\%), Oceania (72-91\%),
South America (23-64\%), Europe (20-97\%), and Asia (9-100\%) [49]. In a recent systematic review and meta-analysis reported from Mainland China among pigs, the IgG seroprevalence was 66\% (95\% CI: $62-$ 71) [50], higher to the IgG seroprevalence found in this study. 


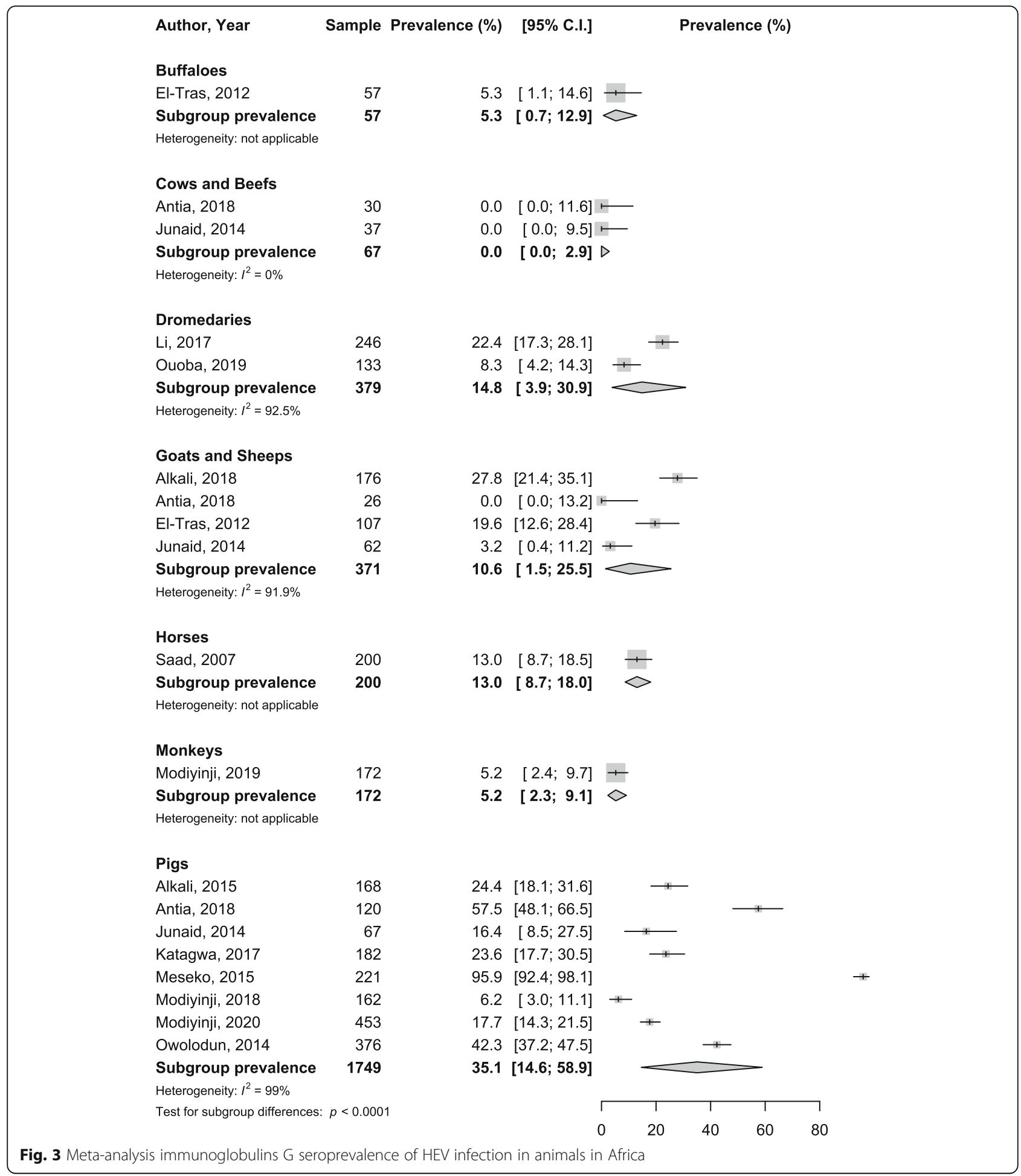

Among sheep and goats, studies in China reported a seroprevalence of IgG varying from 14.3 to $35.2 \%$ [51, 52 ], slightly higher than the finding of this study (10.6\%). The same figure is found for viral prevalence where prevalence data from China $(74.1 \%)$ were higher compared to prevalence in Africa (16.7\%) and Europe (9.2\%)
$[52,53]$. A study reported in the Middle East revealed that $1.5 \%(0.5-4.3)$ of the dromedaries showed evidence of the presence of HEV RNA in their blood samples [54, 55]. The viral prevalence found in this study was $0.2 \%$ (0.0-0.5), slightly lower compared to data from Middle East. Detection of HEV RNA in dromedary in Africa was 


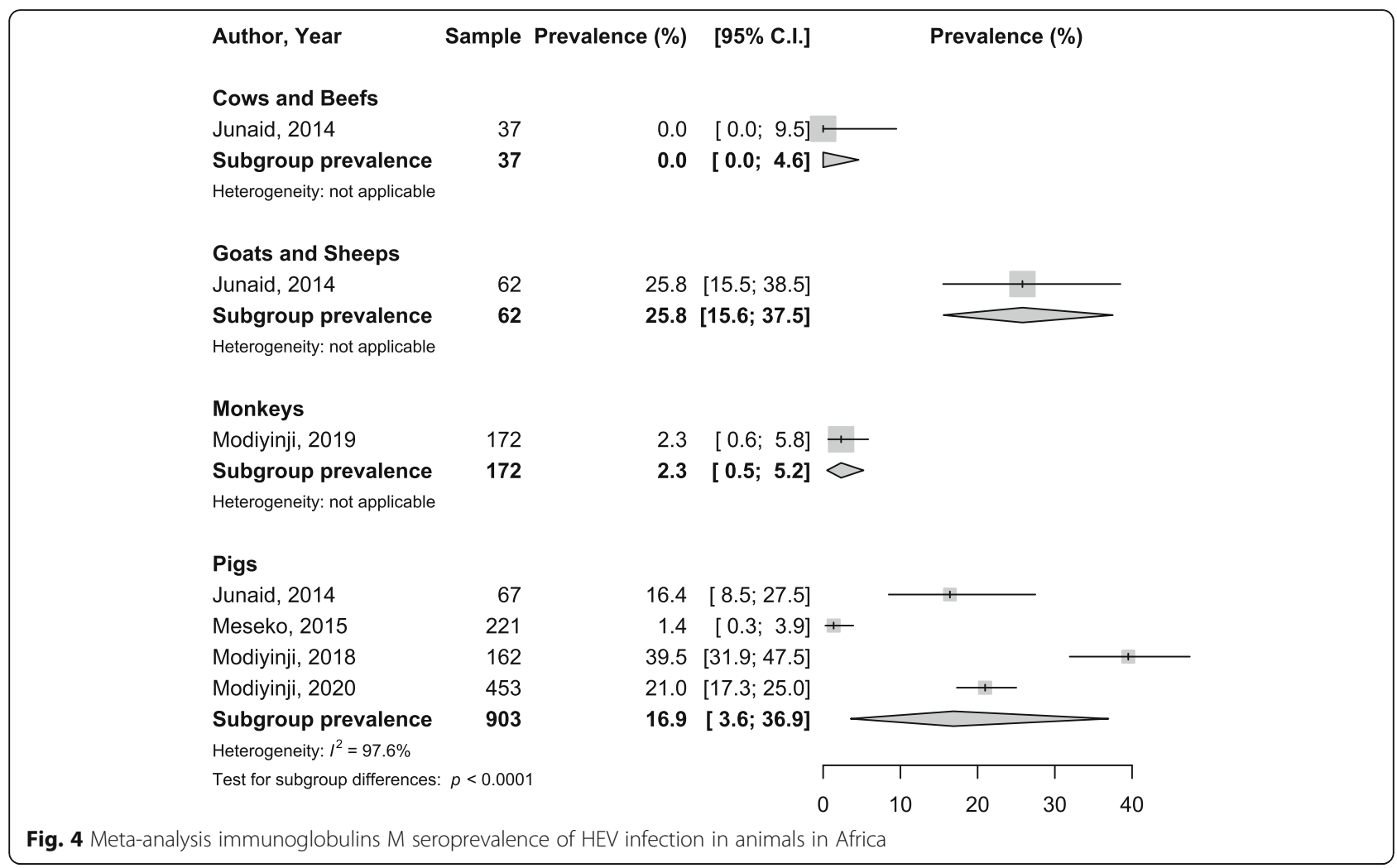

done from blood samples while in Middle East, laboratory analysis was performed on stool. Evidence support that HEV presence in fecal excretion lasts longer than viremia [56]. A study performed in 12 European countries between 2012 and 2015 showed a viral prevalence of rat-HEV genotype 1 in $12.4 \%$ of 508 rats [55], higher than that we found (11.6\%) in this study. This European study used two molecular methods (real-time and conventional PCR) that target different HEV Orthohepevirus species whereas the Egyptian study used only one method (conventional PCR). The high sensitivity of the real-time PCR has been demonstrated in studies and may explain the differences observed in both studies [57].

Among cows, studies conducted in China between 2015 and 2018 showed a viral prevalence that varied between 0 and $37.1 \%$ [58-60]. In a study conducted in Belgium, the prevalence was $0 \%$ for HEV RNA and for IgG anti-HEV [61]. We also found an IgG seroprevalence of $0 \%$ from two studies. Among buffaloes, study conducted in Lao People's Democratic Republic in 2015 showed an IgG seroprevalence of $20 \%$ [62], higher than that we found in Africa (5.3\%).

Table 2 Hepatitis E genotypes in animals in Africa

\begin{tabular}{llll}
\hline Genotypes & Studies & Animals & Countries \\
\hline Rat-HEV genotype 1 & Ghoneim, 2016 [30] & Rats & Egypt \\
& Saad, 2007 [42] & Horses & Cgypt \\
HEV-3 & de Paula, 2013 [27] & Pigs & Cameroon \\
& Modiyinji, 2020 & Pigs & Burkina Faso \\
& Traoré, 2015 [44] & Pigs & Democratic Republic of the Congo \\
& Kaba, 2010 [35] & Pigs & Madagascar \\
& Temmam, 2013 [43] & Pigs & Nigeria \\
HEV-7 & Owolodun, 2014 [41] & Pigs & São Tomé and Príncipe \\
Bat hepevirus & Mesquita, 2019 [38] & Pigs & Somalia; Sudan; Egypt; Kenya
\end{tabular}


To date, HEV infection remains a global public health concern [15]. It is therefore important to implement strategies to curb the burden through public health education and intervention programs, improved clinical practice and innovation in research for this infection [63]. Since, this study demonstrated that some HEV genotypes found in animals were already found in humans, large-scale molecular epidemiological studies are needed in the continent to investigate any HEV zoonotic transmission. This zoonotic transmission was already demonstrated in other settings [2]. This study also shows that other animal species including chickens and wild boar, already identified as a reservoir of HEV are not yet studied in Africa. It is therefore necessary to perform investigations in these animals [64-69].

Although the rate of zoonotic transmission to humans and its public health importance remain unclear [70]; strategies are needed to prevent the potential zoonotic transmission, especially among individuals with direct contact with animals [71]. Since there is no specific treatment for HEV infection, public health policy makers should implement comprehensive public health measures, especially for high group risk individuals in African countries such as educating the farmers, slaughterers, butchers, forest workers, hunters, and veterinarians [72, 73]. A hepatitis $E$ vaccine was licensed in China in 2012, and is currently the only hepatitis E vaccine available. Nonetheless, the World Health Organization did not issue a broad recommendation for its routine use outside of China [74]. Therefore, the development of an effective vaccine to vaccinate humans and also animals is urgently needed in order to minimize the risk of HEV zoonotic transmission [75]. Because cross-species transmission and host tropisms of zoonotic HEV genotypes are not yet understood, surveillance studies of swine and wildlife reservoirs should be conducted to identify all possible human exposure pathways [75].

This study has several limitations. First, we found substantial heterogeneity in the estimation of the overall prevalence of hepatitis E infection. We were able to identify some sources of heterogeneity including biomarkers considered and animal species. However, due to inconsistency in original studies, we were not able to investigate other sources of heterogeneity including population characteristics and variability in sensitivity and specificity of diagnostic methods in original studies. Second, African countries were not uniformly represented and can limit the generalizability of findings to the entire continent. Third, only $20 \%$ of the studies were assessed as having low risk of bias in their methodological quality suggesting that high quality epidemiological studies are needed. However, we were not able to perform sensitivity analysis including only studies with high methodological quality due to paucity of data. Despite these limitations, this study is, to the best of our knowledge, the first systematic review and meta-analysis on prevalence of $\mathrm{HEV}$ infection in animals in Africa. We also included the investigation of different HEV genotypes. Strengths include a comprehensive search strategy and involvement of two independent investigators in all stages of the review process to minimize bias. We did not have publication bias for all outcomes.

\section{Conclusions}

We found a high prevalence of HEV infection in animals in Africa and HEV genotypes close to that of humans. As such, hepatitis E infection should deserve more attention from healthcare providers, researchers, policymakers and stakeholders from many sectors. Some animals in Africa could be the reservoir of HEV, highlighting the need of molecular epidemiologic studies for investigating zoonotic transmission.

\section{Supplementary Information}

The online version contains supplementary material available at https://doi. org/10.1186/s12917-021-02749-5.

Additional file 1: Supplementary Table 1. Individual characteristics of included studies. Supplementary Figure 1. Funnel plot for publication bias of lgG seroprevalence among animals in Africa. Supplementary Figure 2. Funnel plot for publication bias of RNA prevalence among animals in Africa.

Abbreviations

HEV: Hepatitis E virus; IgG: Immunoglobulins G; IgM: Immunoglobulins M; RNA: Ribonucleic acid

Acknowledgments

None.

Authors' contributions

AFM, SK, JJB, FBNS and RN conceived the study and with MN designed the protocol. JJB conceived the search strategy. AFM, SK, and JJB selected studies and extracted data. JJB synthetized and interpreted data. AFM and JJB drafted the manuscript. AFM, SK, FBNS, MAA, MSN, MN, JJB, and RN have critically reviewed the final manuscript for methodological and intellectual content. RN is the guarantor of the review. All authors approved the final version of the manuscript.

Authors' information

This study is a part of the PhD thesis of the first author (AFM).

Funding

This research did not receive any specific funding from a public, commercial or not-for-profit funding agency.

Availability of data and materials

The datasets used and analyzed during the current study are available from the corresponding author on reasonable request.

Ethics approval and consent to participate Not applicable.

Consent for publication

Not applicable. 


\section{Competing interests}

None.

\section{Author details}

'Department of Virology, Centre Pasteur of Cameroon, Yaoundé, Cameroon. ${ }^{2}$ Department of Biology and Animal Physiology, Faculty of Sciences, University of Yaoundé I, Yaoundé, Cameroon. ${ }^{3}$ Department of Epidemiology and Public Health, Centre Pasteur of Cameroon, Yaoundé, Cameroon. ${ }^{4}$ School of Public Health, Faculty of Medicine, University of Paris Sud, Le Kremlin-Bicêtre, France. ${ }^{5}$ Department of Medical Information and Informatics, Rouen University Hospital, Rouen, France.

Received: 31 August 2019 Accepted: 6 January 2021 Published online: 25 January 2021

\section{References}

1. Smith DB, Simmonds P, Jameel S, Emerson SU, Harrison TJ, Meng XJ, Okamoto $\mathrm{H}$, Van der Poel WH, Purdy MA. Consensus proposals for classification of the family Hepeviridae. J Gen Virol. 2014;95(Pt 10):2223-32

2. Spahr C, Knauf-Witzens T, Vahlenkamp T, Ulrich RG, Johne R. Hepatitis E virus and related viruses in wild, domestic and zoo animals: A review; 2017.

3. Purdy MA, Harrison TJ, Jameel S, Meng XJ, Okamoto H, Van der Poel WHM, Smith DB, Ictv Report C. ICTV virus taxonomy profile: Hepeviridae. J Gen Virol. 2017;98(11):2645-6.

4. Woo PC, Lau SK, Teng JL, Cao KY, Wernery U, Schountz T, Chiu TH, Tsang AK, Wong PC, Wong EY, et al. New hepatitis E virus genotype in Bactrian camels, Xinjiang, China, 2013. Emerg Infect Dis. 2016;22(12):2219-21.

5. Spahr C, Knauf-Witzens T, Vahlenkamp T, Ulrich RG, Johne R. Hepatitis E virus and related viruses in wild, domestic and zoo animals: A review. Zoonoses Public Health. 2017;65(1):11-29.

6. Takahashi M, Nishizawa T, Sato H, Sato Y, Jirintai, Nagashima S, Okamoto H. Analysis of the full-length genome of a hepatitis E virus isolate obtained from a wild boar in Japan that is classifiable into a novel genotype. J Gen Virol. 2011; 92(Pt 4):902-8.

7. Lee GH, Tan BH, Teo EC, Lim SG, Dan YY, Wee A, Aw PP, Zhu Y, Hibberd ML, Tan CK, et al. Chronic Infection With Camelid Hepatitis E Virus in a Liver Transplant Recipient Who Regularly Consumes Camel Meat and Milk. Gastroenterology. 2016;150(2):355-7 e353.

8. Rasche A, Saqib M, Liljander AM, Bornstein S, Zohaib A, Renneker S, Steinhagen K, Wernery R, Younan M, Gluecks I, et al. Hepatitis E virus infection in dromedaries, north and East Africa, United Arab Emirates, and Pakistan, 1983-2015. Emerg Infect Dis. 2016;22(7):1249-52.

9. Sridhar S, Teng JLL, Chiu TH, Lau SKP, PCY W. Hepatitis E Virus Genotypes and Evolution: Emergence of Camel Hepatitis E Variants. Int J Mol Sci. 2017;18(4): 869.

10. Sridhar S, Yip CCY, Wu S, Cai J, Zhang AJ, Leung KH, Chung TWH, Chan JFW, Chan WM, Teng JLL, et al. Rat hepatitis E virus as cause of persistent hepatitis after liver transplant. Emerg Infect Dis. 2018;24(12):2241-50.

11. Viral hepatitis [http://apps.who.int/gb/ebwha/pdf_files/WHA63/A63_15-en.pdf]

12. Feldt T, Sarfo FS, Zoufaly A, Phillips RO, Burchard G, van Lunzen J, Jochum J, Chadwick D, Awasom C, Claussen L, et al. Hepatitis E virus infections in HIVinfected patients in Ghana and Cameroon. J Clin Virol. 2013:58(1):18-23.

13. Nimgaonkar I, Ding Q, Schwartz RE, Ploss A. Hepatitis E virus: advances and challenges. Nat Rev Gastroenterol Hepatol. 2018;15(2):96-110.

14. Kim JH, Nelson KE, Panzner U, Kasture Y, Labrique AB, Wierzba TF. A systematic review of the epidemiology of hepatitis E virus in Africa. BMC Infect Dis. 2014;14:308.

15. Purcell RH, Emerson SU. Hepatitis E: an emerging awareness of an old disease. J Hepatol. 2008:48(3):494-503.

16. Modiyinji AF, Bigna JJ, Simo FBN, Nola M, Ndangang MS, Kenmoe S, Njouom R. Epidemiology of hepatitis $E$ virus infection in animals in Africa: a systematic review and meta-analysis protocol. Syst Rev. 2019;8(1):120.

17. Liberati A, Altman DG, Tetzlaff J, Mulrow C, Gotzsche PC, loannidis JP, Clarke M, Devereaux PJ, Kleijnen J, Moher D. The PRISMA statement for reporting systematic reviews and meta-analyses of studies that evaluate health care interventions: explanation and elaboration. J Clin Epidemiol. 2009;62(10):e1-34.

18. Munn Z, Moola S, Lisy K, Riitano D, Tufanaru C. Methodological guidance for systematic reviews of observational epidemiological studies reporting prevalence and cumulative incidence data. Int J Evid Based Healthc. 2015; 13(3):147-53.
19. McGowan J, Sampson M, Salzwedel DM, Cogo E, Foerster V, Lefebvre C. PRESS Peer Review of Electronic Search Strategies: 2015 Guideline Statement. J Clin Epidemiol. 2016;75:40-6.

20. Hoy D, Brooks P, Woolf A, Blyth F, March L, Bain C, Baker P, Smith E, Buchbinder R. Assessing risk of bias in prevalence studies: modification of an existing tool and evidence of interrater agreement. J Clin Epidemiol. 2012;65(9):934-9.

21. Barendregt JJ, Doi SA, Lee YY, Norman RE, Vos T. Meta-analysis of prevalence. J Epidemiol Community Health. 2013;67(11):974-8.

22. Cochran WG. The combination of estimates from different experiments. Biometrics. 1954;10(1):101-29.

23. Higgins JP, Thompson SG. Quantifying heterogeneity in a meta-analysis. Stat Med. 2002:21(11):1539-58.

24. Egger M, Davey Smith G, Schneider M, Minder C. Bias in meta-analysis detected by a simple, graphical test. BMJ (Clinical research ed). 1997; 315(7109):629-34.

25. Alkali BR, Bello M, Hussaini S, Onwuliri CO. Serological evidence and public health implication of hepatitis $E$ virus infection in pigs found in Zaria, Kaduna State. Afr J Microbiol Res. 2015:9(46):2270-4.

26. Alkali BR, Shuaibu AB, Bello M, Abubakar MB, Daneji Al. Sero-prevalence of hepatitis E virus (HEV) genotype 3 in goats from Sokoto Metropolis, Nigeria. Afr J Microbiol Res. 2018;12(33):815-9.

27. de Paula VS, Wiele M, Mbunkah AH, Daniel AM, Kingsley MT, SchmidtChanasit J. Hepatitis E virus genotype 3 strains in domestic pigs, Cameroon. Emerg Infect Dis. 2013;19(4):666-8.

28. Drexler JF, Seelen A, Corman VM, Fumie Tateno A, Cottontail V, Melim Zerbinati R, Gloza-Rausch F, Klose SM, Adu-Sarkodie Y, Oppong SK, et al. Bats worldwide carry hepatitis $E$ virus-related viruses that form a putative novel genus within the family Hepeviridae. J Virol. 2012;86(17):9134-47.

29. El-Tras WF, Tayel AA, El-Kady NN. Seroprevalence of hepatitis E virus in humans and geographically matched food animals in Egypt. Zoonoses Public Health. 2013:60(3):244-51.

30. Ghoneim NH, Abdel-Aziz Abdel-Moein K, Hamza DA, Hagag NM. Occurrence of human hepatitis $\mathrm{E}$ virus in Norway rats: a zoonotic potential with great public health implications. Asian Pac J Trop Dis. 2016;6(9):718-21.

31. Guerrero-Latorre L, Carratala A, Rodriguez-Manzano J, Calqua B, Hundesa A, Girones R. Occurrence of water-borne enteric viruses in two settlements based in eastern Chad: analysis of hepatitis E virus, hepatitis a virus and human adenovirus in water sources. J Water Health. 2011;9(3):515-24.

32. Guthmann JP, Klovstad H, Boccia D, Hamid N, Pinoges L, Nizou JY, Tatay M, Diaz F, Moren A, Grais RF, et al. A large outbreak of hepatitis E among a displaced population in Darfur, Sudan, 2004: the role of water treatment methods. Clin Infect Dis. 2006:42(12):1685-91.

33. Isaeva O, Ahmed Eladly M, Kiuregyan K, Potemkin I, Gordeychuk I, Karlsen A, Zhavoronok S, Mikhailov M. Rabbit hepatitis E virus circulation in endemic and non-endemic regions. J Viral Hepat. 2015;22:121-2.

34. Junaid SA, Agina SE, Jaiye K. Seroprevalence of hepatitis E virus among domestic animals in plateau state-Nigeria. Br Microbiol Res J. 2014;4:924-34.

35. Kaba M, Colson P, Musongela JP, Tshilolo L, Davoust B. Detection of hepatitis $E$ virus of genotype 3 in a farm pig in Kinshasa (Democratic Republic of the Congo). Infect Genet Evol. 2010;10(1):154-7.

36. Katagwa M, Ssemadaali MA, Tumwine G, Majalija S, Mugisha L. Seroprevalence of hepatitis $E$ virus in slaughter pigs and practices of abattoir workers in Kampala, Uganda. Pan Afr Med J. 2017;27(4):8.

37. Li TC, Yoshizaki S, Zhou X, Sentsui H, Shirato K, Matsuyama S, Melaku SK, Bazartseren B, Takeda N, Wakita T. Serological evidence of hepatitis E virus infection in dromedary camels in Ethiopia. J Virol Methods. 2017;246:34-7.

38. Mesquita JR, Istrate C, Santos-Ferreira NL, Ferreira AS, Abreu-Silva J, Veiga J, van der Poel WHM, Nascimento MSJ. Short communication: detection and molecular characterization of hepatitis $E$ virus in domestic animals of Sao Tome and Principe. Trop Anim Health Prod. 2019;51(2):481-5

39. Modiyinji AF, Nola M, Monamele GC, Atsama MA, Njouom R. High seroprevalence of hepatitis $E$ among pigs suggests an animal reservoir in Cameroon. J Infect Dev Ctries. 2018;12(08):676-9.

40. Ouoba JB, Ouedraogo A, Kuan T, Ouoba BL, Rouamba H, Zerbo LH, Moctar S, Traore A, Roques PA, Barro N. Serological evidence of hepatitis E virus in dromedary camels in the Sahelian Zone of West Africa. J Adv Microbiol. 2019:15(4):1-7.

41. Owolodun OA, Gerber PF, Gimenez-Lirola LG, Kwaga JK, Opriessnig T. First report of hepatitis E virus circulation in domestic pigs in Nigeria. Am J Trop Med Hyg. 2014;91(4):699-704. 
42. Saad MD, Hussein HA, Bashandy MM, Kamel HH, Earhart KC, Fryauff DJ, Younan M, Mohamed AH. Hepatitis E virus infection in work horses in Egypt. Infect Genet Evol. 2007;7(3):368-73.

43. Temmam S, Besnard L, Andriamandimby SF, Foray C, RasamoelinaAndriamanivo H, Heraud JM, Cardinale E, Dellagi K, Pavio N, Pascalis H, et al. High prevalence of hepatitis $E$ in humans and pigs and evidence of genotype-3 virus in swine, Madagascar. Am J Trop Med Hyg. 2013;88(2): 329-38.

44. Traore KA, Ouoba JB, Huot N, Rogee S, Dumarest M, Traore AS, Pavio N, Barro N, Roques P. Hepatitis $E$ virus exposure is increased in pork butchers from Burkina Faso. Am J Trop Med Hyg. 2015;93(6):1356-9.

45. Antia RE, Adekola AA. Hepatitis E virus infection seroprevalence and the associated risk factors in animals raised in Ibadan, Nigeria. J Immunoassay Immunochem. 2018;39(5):509-20.

46. Meseko C, Odurinde O, Odaibo G, Olaleye D: Serological Evidence and Risk Factors Associated With Hepatitis E Virus Infection in Pigs and Human at an Intensive Piggery Complex, Lagos Nigeria. J Health Commun 2016;1(1):5.

47. Modiyinji AF, Sanding G, Atsama MA, Monamele CG, Nola M, Njouom R. Serological and molecular investigation of hepatitis $E$ virus in pigs reservoirs from Cameroon reveals elevated seroprevalence and presence of genotype 3. PloS One. 2020;15(2):e0229073.

48. Modiyinji AF, Amougou Atsama M, Monamele Chavely G, Nola M, Njouom R. Detection of hepatitis E virus antibodies among Cercopithecidae and Hominidae monkeys in Cameroon. J Med Primatol. 2019;48(6):364-6.

49. Salines $M$, Andraud M, Rose N. From the epidemiology of hepatitis E virus (HEV) within the swine reservoir to public health risk mitigation strategies: a comprehensive review. Vet Res. 2017:48(1):31.

50. Yue N, Wang Q, Zheng M, Wang D. Prevalence of hepatitis E virus infection among people and swine in mainland China: a systematic review and meta-analysis. Zoonoses Public Health. 2019;66(3):265-75.

51. Wu J, Si F, Jiang C, Li T, Jin M. Molecular detection of hepatitis $E$ virus in sheep from southern Xinjiang, China. Virus Genes. 2015;50(3):410-7.

52. Long F, Yu W, Yang C, Wang J, Li Y, Li Y, Huang F. High prevalence of hepatitis E virus infection in goats. J Med Virol. 2017;89(11):1981-7.

53. Di Martino B, Di Profio F, Melegari I, Sarchese V, Robetto S, Marsilio F, Martella V. Detection of hepatitis E virus (HEV) in goats. Virus Res. 2016;225: 69-72.

54. Woo PC, Lau SK, Teng JL, Tsang AK, Joseph M, Wong EY, Tang Y, Sivakumar $\mathrm{S}$, Xie J, Bai R, et al. New hepatitis E virus genotype in camels, the Middle East. Emerg Infect Dis. 2014;20(6):1044-8.

55. Ryll R, Bernstein S, Heuser E, Schlegel M, Dremsek P, Zumpe M, Wolf S, Pepin M, Bajomi D, Muller $G$, et al. Detection of rat hepatitis $E$ virus in wild Norway rats (Rattus norvegicus) and Black rats (Rattus rattus) from 11 European countries. Vet Microbiol. 2017;208:58-68.

56. Aggarwal R, Goel A. Natural History, Clinical Manifestations, and Pathogenesis of Hepatitis E Virus Genotype 1 and 2 Infections. Cold Spring Harb Perspect Med. 2018;9(7):a032136

57. Zhao C, Li Z, Yan B, Harrison TJ, Guo X, Zhang F, Yin J, Yan Y, Wang Y. Comparison of real-time fluorescent RT-PCR and conventional RT-PCR for the detection of hepatitis E virus genotypes prevalent in China. J Med Virol. 2007;79(12):1966-73

58. Geng Y, Zhao C, Huang W, Wang X, Xu Y, Wu D, Du Y, Liu H, Wang Y. Hepatitis $E$ virus was not detected in feces and milk of cows in Hebei province of China: no evidence for HEV prevalence in cows. Int J Food Microbiol. 2018:291:5-9.

59. Huang F, Li Y, Yu W, Jing S, Wang J, Long F, He Z, Yang C, Bi Y, Cao W, et al. Excretion of infectious hepatitis $E$ virus into milk in cows imposes high risks of zoonosis. Hepatology. 2016;64(2):350-9.

60. Geng Y, Zhao C, Huang W, Wang X, Xu Y, Wu D, Du Y, Liu H, Wang Y. Hepatitis $E$ virus was not detected in feces and milk of cows in Hebei province of China: no evidence for HEV prevalence in cows. Int J Food Microbiol. 2019:291:5-9.

61. Vercouter AS, Sayed IM, Lipkens Z, De Bleecker K, De Vliegher S, Colman R, Koppelman M, Supre K, Meuleman P. Absence of zoonotic hepatitis E virus infection in Flemish dairy cows. Int J Food Microbiol. 2018;281:54-9.

62. Tritz SE, Khounvisith V, Pommasichan S, Ninnasopha K, Keosengthong A, Phoutana V, Camoin M, Hubschen JM, Black AP, Muller CP, et al. Evidence of increased hepatitis $E$ virus exposure in Lao villagers with contact to ruminants. Zoonoses Public Health. 2018;65(6):690-701.

63. Corneillie L, Banda DH, Meuleman P. Animal Models for Hepatitis E virus. Viruses. 2019;11(6):564.
64. Li TC, Chijiwa K, Sera N, Ishibashi T, Etoh Y, Shinohara Y, Kurata Y, Ishida M, Sakamoto S, Takeda N, et al. Hepatitis E virus transmission from wild boar meat. Emerg Infect Dis. 2005;11(12):1958-60.

65. Johne R, Plenge-Bonig A, Hess M, Ulrich RG, Reetz J, Schielke A. Detection of a novel hepatitis E-like virus in faeces of wild rats using a nested broadspectrum RT-PCR. J Gen Virol. 2010;91(Pt 3):750-8.

66. Ivanova A, Tefanova V, Reshetnjak I, Kuznetsova T, Geller J, Lundkvist A, Janson M, Neare K, Velstrom K, Jokelainen $P$, et al. Hepatitis $E$ virus in domestic pigs, wild boars, pig farm workers, and hunters in Estonia. Food Environ Virol. 2015;7(4):403-12.

67. McElroy A, Hiraide R, Bexfield N, Jalal H, Brownlie J, Goodfellow I, Caddy SL. Detection of hepatitis E virus antibodies in dogs in the United Kingdom. PLoS One. 2015;10(6):e0128703.

68. Caballero-Gomez J, Rivero-Juarez A, Cano-Terriza D, Risalde MA, LopezLopez P, Frias M, Jimenez-Ruiz S, Rivero A, Garcia-Bocanegra I. Survey for hepatitis $E$ virus infection in non-human primates in zoos in Spain. Transbound Emerg Dis. 2019;66(4):1771-5.

69. Matczuk AK, Cwiek K, Wieliczko A. Avian hepatitis E virus is widespread among chickens in Poland and belongs to genotype 2. Arch Virol. 2019; 164(2):595-9.

70. Kuniholm MH, Nelson KE. Of organ meats and hepatitis $E$ virus: one part of a larger puzzle is solved. J Infect Dis. 2008;198(12):1727-8.

71. Pavio N, Meng XJ, Renou C. Zoonotic hepatitis E: animal reservoirs and emerging risks. Vet Res. 2010;41(6):46.

72. Lewis HC, Wichmann O, Duizer E. Transmission routes and risk factors for autochthonous hepatitis $\mathrm{E}$ virus infection in Europe: a systematic review. Epidemiol Infect. 2010;138(2):145-66.

73. Pavio N, Doceul V, Bagdassarian E, Johne R. Recent knowledge on hepatitis E virus in Suidae reservoirs and transmission routes to human. Vet Res. 2017 48(1):78.

74. Huang $X$, Huang $Y$, Wagner AL, Chen X, Lu Y. Hepatitis E virus infection in swine workers: a meta-analysis. Zoonoses Public Health. 2019;66(1):155-63.

75. Syed SF, Zhao Q, Umar M, Alagawany M, Ujjan IA, Soomro F, Bangulzai N, Baloch AH, Abd El-Hack M, Zhou EM, et al. Past, present and future of hepatitis E virus infection: zoonotic perspectives. Microb Pathog. 2018;119: $103-8$.

\section{Publisher's Note}

Springer Nature remains neutral with regard to jurisdictional claims in published maps and institutional affiliations.
Ready to submit your research? Choose BMC and benefit from:

- fast, convenient online submission

- thorough peer review by experienced researchers in your field

- rapid publication on acceptance

- support for research data, including large and complex data types

- gold Open Access which fosters wider collaboration and increased citations

- maximum visibility for your research: over $100 \mathrm{M}$ website views per year

At BMC, research is always in progress.

Learn more biomedcentral.com/submissions 